\title{
A szubjektív egészségi állapot egészségszociológiai aspektusai
}

\author{
Health sociological aspects of subjective health state
}

Szerző:

\author{
R. Fedor Anita $\bowtie$ \\ Debreceni Egyetem Egészségügyi Kar, Szociális és Társadalomtudományi Intézet, \\ Egészségszociológiai Tudományos Koordinációs Központ
}

Beküldve: $\quad$ 2019.10. 07.

doi: $\quad$ 10.24365/ef.v60i5.524

\begin{abstract}
Összefoglaló:
Bevezetés: A „Nyíregyháza város életminősége - Háztartáspanel” című kutatás 2008 óta öt hullámban, két-, illetve háromévente mérte fel a városlakók életminőségét. A 2018-as felmérés két szakaszban zajlott. A második szakasz az egészségi állapot felmérésére koncentrált, melyben a mentális és fizikai egészség, valamint a rizikómagatartás vizsgálata mellett helyet kapott az önminősített egészségi állapot felmérése is.
\end{abstract}

Módszertan: Jelen tanulmányunk középpontjában a szubjektív egészségi állapot szociológiai vizsgálata áll. Írásunkban elsősorban a szociodemográfiai, szociokulturális jellemzők, valamint a szocioökonómiai státusz és a szubjektív egészségi állapot összefüggéseit mutatjuk be. Az adatok rögzítését és feldolgozását az SPSS programcsomag 24. verziójának segítségével végeztük. Eredmények: Eredményeink szignifikáns összefüggést mutatnak a családi állapot, az életkor, az iskolai végzettség, a gazdasági aktivitás és a jövedelmi helyzet vonatkozásában is. A családi állapot esetében azt tapasztaltuk, hogy a korábbi vizsgálatoknak ellentmondó összefüggést bizonyítanak az adataink, míg a többi vizsgált változó vonatkozásában a vártnak megfelelő eredmények születtek. Eszerint a fiatalabb életkor, a magasabb iskolai végzettség, a gazdasági aktivitás és a kedvezőbb jövedelmi helyzet pozitívan befolyásolja a szubjektív egészségi állapotot. Következtetések: Eredményeink rávilágítanak az objektív egészségi állapotot befolyásoló szubjektív egészségi állapot vizsgálatának fontosságára. Mindamellett úgy véljük, hogy az ok-okozati összefüggések pontosításához további magyarázó változók bevonására van szükség.

Kulcsszavak: szociodemográfiai jellemzők; szociokulturális jellemzők; szocioökonómiai státusz; szubjektív egészségi állapot; egészségszociológia

\section{Summary:}

Introduction: Since 2008, the Quality of Life in Nyíregyháza research panel has been assessing the quality of life of city dwellers every two years. The 2018 survey was conducted in two phases. The second phase focused on health assessment, which included a review of mental and physical health and risk behavior, as well as self-rated health.

Method: In the focus of our study is the sociological examination of subjective health. In this paper, we present the relationship between socio-demographic and sociocultural characteristics and socioeconomic status and subjective health status among the inhabitants of Nyíregyháza, based on our empirical study conducted in 2018. Data were recorded and processed using SPSS 24.00 for Windows software.

Results: Our results also showed a significant correlation with marital status, age, education, economic activity and income status. In the case of marital status, we found that our data show a contradictory relationship to previous studies, while the other variables examined were expected to produce results that were consistent with expectations. According to this, younger 
age, higher education, economic activity and a more favorable income situation have a positive effect on subjective health.

Findings: Our results highlight the importance of examining the subjective health status that affects objective health. However, we believe that further explanatory variables are needed to clarify the causal relationship between them.

Keywords: socio-demographic characteristics; socio-cultural characteristics; socioeconomic status; subjective health status; health sociology

\section{BEVEZETÉS}

A társadalom tagjainak egészségi állapota, egészségtudatossága rendkívüli jelentőséggel bír. Az egészségtudatos magatartás erősítése, az egészségmegőrzés nemcsak egyéni, de össztársadalmi szinten is fontos, melynek hozadéka egyéni és gazdasági szinten is érzékelhető.

Az elmúlt évtizedben jelentős változásokat tapasztalhattunk az egyénre vonatkozó egészségkép alakulásában. Az egészségmegőrzés, az egészséges életmód követésének fontossága, az ehhez szorosan kapcsolódó tudatos fogyasztás a médiában is egyre gyakrabban - néha egymásnak ellentmondó információkat közvetítve - jelenik meg. Ez tekinthető a modernizáció egyik egészségügyi vívmányaként is, melynek hatására jelentősen többet törődünk az egészségünkkel, a környezetünkkel, a személyi higiénével. Ennek eredményeképpen kijelenthető, hogy a társadalom egyes szintjein az egészségtudatos magatartás jelentős emelkedést mutat, az egészség tulajdonképpen a kultúra részévé vált. ${ }^{1,2}$

Az egészségszociológiai vizsgálatok azt mutatják, hogy a társadalmi-gazdasági helyzet jelentősen befolyásolja az egészségi állapotot.

Jelen tanulmányunk középpontjában a szubjektív egészségi állapot szociológiai vizsgálata áll. Írásunkban elsősorban a szociodemográfiai, szociokulturális jellemzők, valamit a szocioökonómiai státusz és a szubjektív egészségi állapot összefüggéseit mutatjuk be. Célunk, hogy rávilágítsunk arra, hogy a társadalmi különbségek alakítják-e és ha igen, hogyan a szubjektív egészségi állapotot. Fontos megjegyezni, hogy a különbségeket az egyes szociodemográfiai jellemzőkön túl elsősorban a rétegképző ismérvek segítésével azonosítjuk, úgymint iskolai végzettség, gazdasági aktivitás, jövedelem.
Elemző munkánkban a „Nyíregyháza város életminősége - Háztartáspanel" elnevezésű kutatás egészségi állapotot felmérő adatbázisát (EgészségPanel) használjuk.

\section{Az empirikus vizsgálat bemutatása}

A „Nyíregyháza város életminősége - Háztartáspanel" címú kutatás 2008 óta öt hullámban, két-, illetve háromévente mérte fel a városlakók életminőségét. A mintaválasztás módszerét és általános jellemzőinek leírását jelen különszám módszertani bevezetése tárgyalja.'

A 2018-as felmérés két szakaszban zajlott. Az első szakaszban, 2017 őszén 541 háztartást értek el, a második szakaszban, 2018 tavaszán pedig 391-et, melyből 386-ot vontak be az elemzésbe. A Panelkutatás Egészségpanel része az első felmérési szakaszban egyetlen kérdéssel érintette az egészségre, egészségügyre vonatkozó témakört, a második szakasz pedig az egészségi állapot felmérésére koncentrált, melyben a mentális és fizikai egészség, valamint a rizikómagatartás vizsgálata mellett helyet kapott az önminősített egészségi állapot felmérése is.

A szubjektív egészségi állapot általános mintázatát két kérdés segítségével mértük. A „Hogyan jellemezné általában egészségi állapotát?" kérdésre adott válaszok arról adnak információt, hogy a válaszadó a megkérdezés pillanatában hogyan vélekedik saját egészségi állapotáról, saját bevallása szerint hogyan érzi magát. A másik kérdés arra irányult, hogy felmérjük, a megkérdezettek mit gondolnak arról, ők maguk mennyiben tudják befolyásolni saját egészségüket. A kérdést így szólt: „Véleménye szerint Ön mennyit tehet az egészségéért?" A felmérésbe bevont nyíregyháziak véleményét mindkét esetben Likert-skálán mértük.

\footnotetext{
¡Takács P, Fábián G, Jávorné Erdei R. A 2018-as Nyíregyháza város életminősége Háztartáspanel kutatás általános és EgészségPanel szakaszainak mintavételi jellemzői. Egészségfejlesztés, LX. évfolyam, Jubileumi lapszám, doi: 10.24365/ef.v60i5.523.
} 
A „Hogyan jellemezné általában egészségi állapotát?” kérdésre a „nagyon jó/jó/elfogadható /rossz/nagyon rossz” lehetőségek; a "Véleménye szerint Ön mennyit tehet az egészségéért?" kérdésre a "nagyon sokat/sokat/keveset/semmit" lehetőségek közül választhattak a megkérdezettek. Elemzésünkben az önminősített egészségi státuszt körülíró változókat tekintjük függő változónak, míg a nemet, életkort, iskolai végzettséget, jövedelmet, foglalkoztatottságot magyarázó változóként jelöljük.

Az adatok rögzítését és feldolgozását az SPSS programcsomag 24. verziójának segítségével végeztük. Elemző munkánkban egyváltozós és többváltozós elemzési technikákat is alkalmaztunk. Az elemzés során a leggyakrabban használt többváltozós forma a kereszttábla-elemzés volt, a változók közötti összefüggés vizsgálatát pedig khí-négyzet próbával végeztük el.

Statisztikai elemzésünkben a következő magyarázó változók csoportját alkalmaztuk mint a vizsgált populáció szubjektív egészségi állapotának prediktorait:

Szociodemográfiai jellemzők:

1. Életkori hatások: A megkérdezett betöltött és szülési életkora

2. Nem: férfi/nő

3. Családi állapot

Szociokulturális jellemzők:

1. Legmagasabb iskolai végzettség

Szocioökonómiai jellemzők:

1. Gazdasági aktivitási jellemzők hatása I.: dolgozott-e, rendelkezett-e munkahellyel a megkérdezés idején

2. Gazdasági aktivitási jellemzők hatása II.: hetente átlagosan hány órát dolgozott

3. Jövedelem hatás: havi nettó jövedelem

A szubjektív egészséget mérő kérdések közül pedig a következőkre koncentráltunk (függő változók):

1. Hogyan jellemezné általában egészségi állapotát?

2. Véleménye szerint Ön mennyit tehet az egészségéért?

\section{Társadalmi háttérváltozók}

Elemzésünk első részében a felmérésben részt vett nyíregyházi lakosokra vonatkozó - a szubjektív egészségi állapot megismeréséhez releváns - alapadatokat közöljük. Az Eredmények részben pedig részletesen bemutatjuk, hogy az egyes bevont változók mennyiben magyarázzák az önminősített egészségi állapotot.

A válaszadók 54,6\%-a nő, 45,4\%-a férfi. Családi állapot szerint 18,8\%-uk egyedülálló, 52,3\% házas, 15,3\%-uk élettársi kapcsolatban élt a megkérdezés idején. Az elváltak aránya 9,7\%, az özvegyeké 4\% volt.

Életkori megbontás alapján a legtöbben a 41-55 éves (26,6\%), valamint a 65 év feletti korosztályhoz tartoznak (26,6\%), majd a 26-40 éves korosztály tagjai (20,7\%), utánuk pedig az 56-64 évesek $(14,9 \%)$ következnek a sorban. Legkevesebben a 18-25 évesek vannak, ők a vizsgált minta 11,2\%-át teszik ki.

A megkérdezettek 54,8\%-a dolgozott, 41,6\%-a pedig nem dolgozott a felmérés időpontjában. Érdekes lehetett volna még az elemzés szempontjából, hogy akik nem dolgoztak, azok közül hányan voltak például gyermekgondozási szabadságon, vagy voltak ténylegesen munka nélkül vagy esetleg már nyugdíjban. Ezen információk ismerete további öszszefüggések felderítését tette volna lehetővé.

A jövedelemszerző tevékenységet végzők 51,9\%ára a klasszikusnak mondható, heti 40 órás munkavégzés a jellemző. A következő legnépesebb csoport heti 48-50 órát dolgozik. Ennél magasabb heti óraszámról a válaszadók 8,6\%-a számolt be. Minden ötödik megkérdezettre részmunkaidős foglalkoztatás (legfeljebb heti 35 óra) jellemző, ezen belül is a heti 20 órában dolgozók vannak a legtöbben.

300 ezer forint feletti nettó jövedelemből él a válaszadó nyíregyháziak 26,7\%-a. Minden hatodik válaszadó 151 ezer és 250 ezer forint közötti összegből gazdálkodik havonta. Kevesen (8,6\%) keresnek 251 ezer és 300 ezer forint közötti összeget. A két alsó jövedelemhatár a lakosok 12,5\%-ára jellemző.

\section{EREDMÉNYEK}

Szubjektív egészségi állapot jellemzői

A felmérésben részt vevő nyíregyházi lakosok önminősített egészségi állapotáról a következő mondható el: „jó"-nak, illetve „nagyon jó”-nak ítéli meg az egészségi állapotát 44,4\%. A semlegesnek tekinthető „elfogadható”, se nem jó, se nem rossz kategóriába tartozik több mint minden harmadik válaszadó. 10\% pedig „rossz”-nak, illetve „nagyon 
rossz"-nak minősítette az egészségi állapotát. A legtöbben és ráadásul közel azonos arányban vannak a „jó” és „elfogadható” egészségi állapotról vallók. [1. táblázat]
Arra kértük a válaszadókat, hogy véleményezzék, ők maguk mennyit tehetnek saját egészségük érdekében. 83,4\% gondolja úgy, hogy inkább befolyásolhatja saját egészségét, de valamivel több mint minden nyolcadik ember mondta azt, hogy kevésbé múlik rajta egészségi állapotának alakulása, és 3,4\% szerint semmit nem tehet egészsége érdekében. [2. táblázat]

1. táblázat: Hogyan jellemezné általában egészségi állapotát? (\%)

\begin{tabular}{|l|c|c|c|c|c|}
\hline & \multicolumn{5}{|c|}{ Hogyan jellemezné általában egészségi állapotát? } \\
\hline & Nagyon jó & Jó & Elfogadható & Rossz & Nagyon rossz \\
\hline megoszlás N=384 & 17,2 & 37,2 & 36,7 & 7,6 & 1,3 \\
\hline
\end{tabular}

Forrás: saját szerkesztés

2. táblázat: Véleménye szerint Ön mennyit tehet az egészségéért? (\%)

\begin{tabular}{|c|c|c|c|c|}
\hline & Nagyon sokat & Sokat & Keveset & Semmit \\
\hline megoszlás N=381 & 32,5 & 50,9 & 13,1 & 3,4 \\
\hline
\end{tabular}

Forrás: saját szerkesztés

\section{Szociodemográfiai jellemzők hatása a szubjektív egészségi állapotra}

Arra is kíváncsiak voltunk, hogy az egyes szociodemográfiai tényezők mennyiben befolyásolják az önminősített egészségi állapotot. Eredményeink szerint az életkor és a családi állapot szignifikáns kapcsolatot mutat az egészségi állapot értékelésé-

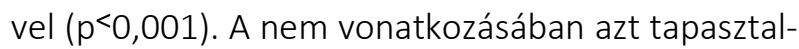
tuk, hogy a férfiak valamivel jobbnak érzik egészségi állapotukat, mint a nők. A „jó” és „elfogadható” kategóriákban mért megoszlások közel azonosak a két nem vonatkozásában, a két kevésbé kedvező, „rossz” és „nagyon rossz” értékelést választók körében a nők vannak többen. [3. táblázat]

Landa és mtsai eredményei egyértelműen rámutatnak arra, hogy a családi állapot nagymértékben befolyásolja az egészségi állapotot és az ezzel szorosan összefüggő érzékelt stressz szintjét. Ebből a szempontból a partnerrel együtt élők (házasok, élettársi kapcsolatban élők) előnye figyelhető meg. ${ }^{3}$ Saját vizsgálatunk eredményei azonban ezzel ellentétes összefüggést mutatnak. A családi állapot és egészségi állapot megítélésének összefüggései az egyedülállók csoportjába tartozók előnyéről tanúskodnak. Körükben a legmagasabb az egészségi állapotukat „nagyon jó”-nak értékelők aránya (38,6\%). Itt azért érdemes megemlíteni az egészségi állapotot köztudottan befolyásoló életkori hatást, mivel feltételezhető, hogy ők a minta legifjabbjai. Vélhetően ez is alakítja ennek a csoportnak a véleményalkotását. (Az életkori hatás meghatározó voltára a későbbiekben még részletesen kitérünk.) Mindemellett az együtt élők közötti érzelmi kapcsolat minősége, a nem megfelelő családi kapcsolatok szintén felülírhatják a családi állapot egészségi állapotra gyakorolt, vélt pozitív hatását. Ennek mérését következő vizsgálatunkban feltétlenül fontosnak tartjuk, az ok-okozatok pontos megismeréséhez, hiszen a nem kiegyensúlyozott, feszültségteli partnerkapcsolat ellenkezóleg hat az egészségi állapotra, főleg a férfiak körében. A házasok esetében mindössze 10,8\% nyilatkozott úgy, hogy „nagyon jó”-nak ítéli meg az egészségi állapotát, amely közel azonos az elváltak véleményével (!). 
A „jó” értékelés a házas családi állapotúaknál volt a legmagasabb, míg az „elfogadható” minősítésben jelentős átfedés figyelhető meg - az egyedülállók csoportjának kivételével - minden családi állapot- kategória között. "Rossz” és "nagyon rossz” egészségi állapotról az özvegyek nyilatkoztak. Ettől jóval lemaradva, második helyen vannak az elváltak. [4. táblázat]

3. táblázat: Hogyan jellemezné általában egészségi állapotát? (\%)

\begin{tabular}{|c|c|c|c|c|c|c|}
\hline $\begin{array}{c}\text { A megkérdezett } \\
\text { neme }\end{array}$ & Nagyon jó & Jó & Elfogadható & Rossz & $\begin{array}{c}\text { Nagyon } \\
\text { rossz }\end{array}$ & Összesen \\
\hline Férfi (N=140) & 20,0 & 37,1 & 37,9 & 3,6 & 1,4 & 100,0 \\
\hline Nö (N=244) & 15,6 & 37,3 & 36,1 & 9,8 & 1,2 & 100,0 \\
\hline
\end{tabular}

$\mathrm{p}=0,219$

Forrás: saját szerkesztés

4. táblázat: Hogyan jellemezné általában egészségi állapotát? (\%)

\begin{tabular}{|c|c|c|c|c|c|c|}
\hline $\begin{array}{c}\text { A megkérdezett } \\
\text { családi állapota } \\
\text { N=368 }\end{array}$ & Nagyon jó & Jó & Elfogadható & Rossz & Nagyon rossz & Összesen \\
\hline Egyedülálló & 38,6 & 34,3 & 22,9 & 1,4 & 2,9 & 100,0 \\
\hline Házas & 10,8 & 41,8 & 38,1 & 8,8 & 0,5 & 100,0 \\
\hline Élettárssal él & 21,4 & 35,7 & 41,1 & 1,8 & 0,0 & 100,0 \\
\hline Elvált & 11,1 & 30,6 & 41,7 & 13,9 & 2,8 & 100,0 \\
\hline Özvegy & 0,0 & 26,7 & 40,0 & 26,7 & 6,7 & 100,0 \\
\hline
\end{tabular}

$p<0,001$

Forrás: saját szerkesztés

Általánosságban elmondható, hogy a megkérdezettek többsége úgy véli, hogy ő maga is tehet az egészségi állapota megőrzéséért. Túl nagy eltéréseket nem tapasztaltunk az egyes családi állapotúak tekintetében, bár az is igaz, hogy leginkább az egyedülállók gondolkodnak úgy, hogy nagyon sok szerepük van egészségük megóvásában. Ebből a szempontból a legpesszimistábbnak az özvegyek és az elváltak bizonyultak. [5. táblázat]

Korábbi vizsgálatok pozitív erős korrelációt mutattak ki az életkor és a szubjektív egészségi állapot között, vagyis kijelenthető, hogy az életkor emelkedésével romlik a saját egészségi állapot megítélése. ${ }^{4,5,6,7}$ Deaton nemzetközi összehasonlító vizsgálatában arra is rámutatott, hogy az egészségi állapot romlásának életkorral emelkedő üteme nagymér- tékben függ az adott ország gazdasági helyzetétől. ${ }^{8}$ Hayo vizsgálatai szerint a szubjektív jóllét az életkor függvényében $U$ alakú görbét írt le, melynek minimumpontja 40 év körül van. ${ }^{9,10}$ (Jelen vizsgálatunkban a szubjektív jóllét jellemzőit nem vizsgáljuk.) Saját empirikus vizsgálatunk eredményei visszaigazolják a korábbi kutatások konklúzióját. A legjobbnak a legfiatalabbak ítélik egészségi állapotukat. 42,9\%-uk nyilatkozta azt, hogy „nagyon jó” az egészségi állapota. Ahogyan haladunk előre az egyes életkori csoportokban, úgy csökken a hasonlóan vélekedők aránya. 40 éves kortól jelentős romlásról számolhatunk be, s a 60 év feletti korosztálynál ez a megoszlás már csak $3 \%$, mely vélhetően összefügg az életkor emelkedésével romló, objektív egészségi állapottal. [6. táblázat] 
Szintén a fiatalok előnye rajzolódik ki a „Véleménye szerint Ön mennyit tehet az egészségéért?" kérdésre adott válaszokból. A 18-25 évesek több mint fele mondta azt, hogy nagyon sokat tehet saját egészsége alakulásáért. Valamivel kevesebben gondolják ugyanezt a 26-40 éves korosztály tagjai közül s közel ennyien vélik úgy, hogy ha nagyon sokat nem is, de sokat tehenek egészségük érdekében. A 41-55 éves és 65 év felettiek közül minden harmadik, az 56-64 évesek közül pedig minden negyedik válaszadó gondolkodik hasonlóan. [7. táblázat]

5. táblázat: Véleménye szerint Ön mennyit tehet az egészségéért? (\%)

\begin{tabular}{|c|c|c|c|c|}
\hline $\begin{array}{c}\text { A megkérdezett családi } \\
\text { állapota N=368 }\end{array}$ & Nagyon sokat & Sokat & Keveset & Semmit \\
\hline Egyedülálló & 40,0 & 47,1 & 10,0 & 2,9 \\
\hline Házas & 29,8 & 56,0 & 12,0 & 2,1 \\
\hline Élettárssal él & 35,7 & 48,2 & 14,3 & 1,8 \\
\hline Elvált & 25,0 & 50,0 & 13,9 & 11,1 \\
\hline Özvegy & 26,7 & 46,7 & 20,0 & 6,7 \\
\hline
\end{tabular}

Forrás: saját szerkesztés

6. táblázat: Hogyan jellemezné általában egészségi állapotát? (\%)

\begin{tabular}{|c|c|c|c|c|c|c|}
\hline $\begin{array}{c}\text { A megkérdezett élet- } \\
\text { kora (év) N=374 }\end{array}$ & Nagyon jó & Jó & Elfogadható & Rossz & Nagyon rossz & Összesen \\
\hline $18-25$ & 42,9 & 28,6 & 23,8 & 2,4 & 2,4 & 100,0 \\
\hline $26-40$ & 37,2 & 50,0 & 11,5 & 1,3 & 0,0 & 100,0 \\
\hline $41-55$ & 10,1 & 50,5 & 36,4 & 2,0 & 1,0 & 100,0 \\
\hline $56-64$ & 10,9 & 29,1 & 43,6 & 12,7 & 3,6 & 100,0 \\
\hline $65+$ & 3,0 & 22,0 & 56,0 & 18,0 & 1,0 & 100,0 \\
\hline
\end{tabular}

$p<0,001$

Forrás: saját szerkesztés

7. táblázat: Véleménye szerint Ön mennyit tehet az egészségéért? (\%)

\begin{tabular}{|c|c|c|c|c|}
\hline $\begin{array}{c}\text { A megkérdezett életkora } \\
\text { (év) N=371 }\end{array}$ & Nagyon sokat & Sokat & Keveset & Semmit \\
\hline $18-25$ & 52,4 & 42,9 & 4,8 & 0,0 \\
\hline $26-40$ & 47,4 & 48,7 & 2,6 & 1,3 \\
\hline $41-55$ & 32,3 & 56,6 & 8,1 & 3,0 \\
\hline $56-64$ & 24,1 & 55,6 & 16,7 & 3,7 \\
\hline $65+$ & 32,6 & 51,5 & 12,7 & 3,2 \\
\hline
\end{tabular}

$p^{<0,001}$

Forrás: saját szerkesztés 
Szociokulturális jellemzők hatása a szubjektív egészségi állapotra

Kopp és Mészáros a boldogságot és egészségi állapotot meghatározó háttérváltozók feltárásánál egyértelműen rámutatnak, hogy az önértékeléses egészségi állapot és boldogság megítélését jelentősen és pozitívan határozza meg az iskolai végzettség. Ezzel szemben a nemzetközi szakirodalom számos olyan eredménye ismert, mely árnyalja ezt az összefüggést. ${ }^{11,12}$ Azonban a magyar populáció körében lebonyolított vizsgálatok erős pozitív kapcsolatot tártak fel az említett két változó között, míg például Nagy-Britanniában negatív összefüggés mutatkozott. Mindez arra enged következtetni, hogy az iskolai végzettség hatása más magyarázó változók bevonása esetén módosulhat, valamint hogy az adott ország általános társadalmi-gazdasági-kulturális környezete eltérő módon tipizálja a szubjektív egészségi állapotot. ${ }^{10} \mathrm{~A}$ korábbi nyíregyházi vizsgálatok a magyarországi eredményekkel megegyező összefüggéseket mutatnak. 5,6,7,13

A 2018-as nyíregyházi adatfelvétel véleményalkotásából kitűnik, hogy a válaszadók többsége a "jó" $(37,2 \%)$ és „elfogadható” (36,7\%) jelzővel minősítette saját egészségi állapotát. Iskolai végzettség szerinti megbontásban a vártnak megfelelően jelentős eltéréséket tapasztaltunk. Eredményeink szerint az iskolai végzettség és az önértékelt egészségi állapot között statisztikailag releváns összefüggés van $\left(p^{<0,001)}\right.$. Legnagyobb arányban az érettségivel és technikusi végzettséggel rendelkezők válaszolták azt, hogy „nagyon jó” az egészségi állapotuk. Ettől csak kissé marad el a diplomások véleménye, míg a legfeljebb nyolc osztállyal, valamint szakmunkás bizonyítvánnyal rendelkezők körében nagyon alacsony azok aránya, akik úgy gondolják, hogy „nagyon jó” az egészségi állapotuk. [8. táblázat] Ebben a csoportban azok vannak a legtöbben, akik „elfogadhatónak” tartják jelenlegi egészségi állapotukat, míg a többi iskolai végzettség szerinti csoportban a "jó” kategóriába sorolta magát a válaszadók legnagyobb része. Ezen belül is kiemelkednek az egyetemi $(56,1 \%)$ és föiskolai $(46,5 \%)$ diplomával rendelkezők. Ebből a szempontból az egyetemet végzettek közel 20\%-kal, míg a főiskolát végzettek 10\%-kal térnek el az átlagtól (37,2\%). [8. táblázat]

Még inkább nyomon követhetőek az eltérések, ha összevonjuk a két szélső válaszkategóriát („nagyon jó” és „jó", „rossz” és „nagyon rossz”). Élesen kirajzolódik az egyetemi végzettséggel rendelkezők előnye a többi csoporthoz képest. Még a másik diplomás kontingenstôl is 13,3\%-kal eltér a magukat „nagyon jó” és "jó" egészségi állapotban tudók ya. Ez a legalacsonyabb iskolai végzettségú csoport adatainak a kétszerese. Az is látható, hogy a "rossz" és "nagyon rossz" csoportban az alacsony iskolai végzettségűek felülreprezentáltak, közel minden nyolcadik ember vélekedik kedvezőtlenül saját egészségi állapotáról. [9. táblázat]

Saját sorsunk irányításába vetett hitünket számos tényező befolyásolja. Jelen vizsgálatunk eredményei azt támasztják alá, hogy a megszerzett legmagasabb iskolai végzettség is az egyik ilyen magyarázó változó az egészségmegőrzés vonatkozásában. Ahogyan már fentebb bemutattuk, a legtöbben úgy vélték, hogy "sokat” tehetnek saját egészségük érdekében (50,9\%), és minden harmadik ember gondolta csak úgy, hogy "nagyon sokat” tehet ebben az ügyben. Azonban, ha iskolai végzettség szerint vizsgáljuk a válaszokat, akkor azt látjuk, hogy a legmagasabb iskolai végzettségűek többsége hisz abban, hogy nagyon sokat tud tenni saját egészségéért, hiszen a válaszadók közel fele így nyilatkozott. Valamivel kevesebben, de még mindig meghatározó arányban voltak azok, akik azt mondták, hogy sok múlik, illetve múlhat saját hozzáállásukon, életmódjukon (43,9\%). Ha összevonjuk e két válaszlehetőséget megjelölők számát („nagyon sokat” és „sokat” tehetek) azt látjuk, hogy az egyetemi diplomával rendelkezők több mint 90\%-a meg van győződve arról, hogy befolyásolhatja egészségét. A legfeljebb nyolc osztállyal rendezők véleménye jelentősen különbözik ettől. Körükben mindössze 12,1\% véli úgy, hogy "nagyon sokat” tehet az egészségéért. Nagyságrendileg ehhez az arányhoz hasonlóan alakult a szakiskolát, szakmunkásképzőt végzettek véleménye. Az érettségizettek véleményétől mutatkozik egy nagyobb „ugrás” az egészségi állapot befolyásolását illetően, és válik egyre optimistábbá az egyén szerepének megítélése. Aggasztó, hogy a két kevésbé kvalifikált csoport tagjai milyen nagy arányban vélekednek úgy, hogy keveset, illetve semmit sem tehetnek egészségük megőrzéséért. $\mathrm{Az}$ érettségivel nem rendelkezők közül minden harmadik megkérdezett a pesszimisták csoportjához tartozik. [10. táblázat] 
8. táblázat: Hogyan jellemezné általában egészségi állapotát? (\%)

\begin{tabular}{|c|c|c|c|c|c|c|}
\hline $\begin{array}{l}\text { A megkérdezett iskolai végzettsége } \\
\qquad \mathrm{N}=369\end{array}$ & $\begin{array}{l}\text { Nagyon } \\
\text { jó }\end{array}$ & Jó & Elfogadható & Rossz & $\begin{array}{l}\text { Nagyon } \\
\text { rossz }\end{array}$ & $\begin{array}{l}\text { Össze- } \\
\text { sen }\end{array}$ \\
\hline legfeljebb 8 általános iskola N=87 & 9,2 & 23,0 & 55,2 & 11,5 & 1,1 & 100,0 \\
\hline szakiskola, szakmunkásképző N=58 & 6,9 & 22,4 & 60,3 & 10,3 & 0,0 & 100,0 \\
\hline $\begin{array}{c}\text { szakközépiskolai, gimnáziumi érett- } \\
\text { ségi } N=109\end{array}$ & 23,9 & 29,4 & 27,5 & 6,4 & 2,8 & 100,0 \\
\hline $\begin{array}{l}\text { érettségit követő, nem felsőfokú } \\
\text { szakképzés, technikum N=59 }\end{array}$ & 23,7 & 39,0 & 28,8 & 3,4 & 5,1 & 100,0 \\
\hline főiskola, alapképzés N=71 & 15,5 & 46,5 & 31,0 & 7,0 & 0,0 & 100,0 \\
\hline egyetem, mesterképzés N=41 & 19,5 & 56,1 & 19,5 & 2,4 & 2,4 & 100,0 \\
\hline
\end{tabular}

$p^{<0,001}$

Forrás: saját szerkesztés

9. táblázat: Hogyan jellemezné általában egészségi állapotát? (\%)

\begin{tabular}{|c|c|c|c|c|}
\hline $\begin{array}{l}\text { A megkérdezett iskolai végzettsége } \\
\qquad \mathrm{N}=369\end{array}$ & Nagyon jó/Jó & Elfogadható & $\begin{array}{c}\text { Rossz/ } \\
\text { Nagyon rossz }\end{array}$ & Összesen \\
\hline legfeljebb 8 általános iskola N=87 & 32,2 & 55,2 & 12,6 & 100,0 \\
\hline szakiskola, szakmunkásképző N=58 & 29,3 & 60,3 & 10,3 & 100,0 \\
\hline $\begin{array}{c}\text { szakközépiskolai, gimnáziumi } \\
\text { érettségi } \mathrm{N}=109\end{array}$ & 53,3 & 27,5 & 9,2 & 100,0 \\
\hline $\begin{array}{c}\text { érettségit követő, nem felsőfokú } \\
\text { szakképzés, technikum N=59 }\end{array}$ & 62,7 & 28,8 & 8,5 & 100,0 \\
\hline főiskola, alapképzés N=71 & 62,0 & 31,0 & 7,0 & 100,0 \\
\hline egyetem, mesterképzés N=41 & 75,6 & 19,5 & 4,8 & 100,0 \\
\hline
\end{tabular}

$p^{<0,001}$

Forrás: saját szerkesztés

10. táblázat: Véleménye szerint Ön mennyit tehet az egészségéért? (\%)

\begin{tabular}{|c|c|c|c|c|}
\hline $\begin{array}{l}\text { A megkérdezett iskolai végzettsége } \\
\qquad \mathrm{N}=367\end{array}$ & Nagyon sokat & Sokat & Keveset & Semmit \\
\hline legfeljebb 8 általános iskola $\mathrm{N}=33$ & 12,1 & 48,5 & 36,3 & 3,0 \\
\hline szakiskola, szakmunkásképző N=56 & 16,1 & 60,7 & 19,6 & 3,6 \\
\hline $\begin{array}{l}\text { szakközépiskolai, gimnáziumi } \\
\text { érettségi } N=109\end{array}$ & 35,7 & 49,4 & 11,2 & 2,7 \\
\hline $\begin{array}{l}\text { érettségit követő, nem felsőfokú } \\
\text { szakképzés, technikum N=57 }\end{array}$ & 40,4 & 47,4 & 7,0 & 5,3 \\
\hline főiskola, alapképzés N=71 & 38,0 & 53,5 & 5,6 & 2,8 \\
\hline egyetem, mesterképzés N=41 & 46,4 & 43,9 & 7,3 & 2,4 \\
\hline
\end{tabular}

$p^{<0,003}$

Forrás: saját szerkesztés 
Szocioökonómiai jellemzők hatása a szubjektív egészségi állapotra

A foglalkoztatási helyzetet körbejáró írásainkban többször kiemeltük, hogy a munka milyen fontos értéket jelent a mai magyar társadalomban, s annak hiánya milyen mélyen hat az életminőséget meghatározó számos területen. ${ }^{14,15,16,17}$ A munka központi szerepére apellálva ki kell emelni, hogy a munkavégzés nem más, mint a szükségletek kielégítésének egyik fontos eszköze, a társadalmi részvétel formája, a kultúra, a társadalmi beágyazódás alapja. A munka - és itt elsősorban a munkahelyen végzett, illetve a bérrel és szolgáltatásokkal elismert társadalmi szerepére utalva - a modern társadalmakban biztonságot jelent, elsősorban azért, mert a munkavégzésből származó jövedelem biztosítja a megélhetés alapvető feltételeit. A munka nélkül élőknek mindemellett számos, a munkavégzéshez mint feltételhez kapcsolódó szolgáltatások, ellátások (társadalombiztosítás) hiányával kell számolniuk.

A munkanélküliség annak időtartamától függően egyrészt kirekesztődéshez vezet, másrészt a jövedelemkiesésből származó hatása mellett csökkenti az élettel való elégedettséget is. ${ }^{18}$ Ez kedvezőtlenül befolyásolja az önminősített egészségi állapotot. Mindezen túl a munkanélküliség nemcsak magára a munka nélkül lévő személyre gyakorol kedvezőtlen hatást, hanem családtagjaira is. ${ }^{10}$

A munkából való kiesés veszélyezteti a megélhetést, a különböző, addig megszokott tevékenységekben való részvétel biztosítását, hiszen a munka hiánya maga után vonja a jövedelmi helyzet romlását, mely szintén kedvezőtlenül hat a szubjektív egészségi állapotra, jóllétre.
Elemzésünk ezen részében azt tárjuk fel, hogy a gazdasági aktivitás milyensége, a heti munkaidő mennyisége, valamint a jövedelmi helyzet hogyan tipizálja az önminősített egészségi állapotot a nyíregyházi populáció vonatkozásában.

Empirikus vizsgálatunkban szignifikáns összefüggés rajzolódott ki a szubjektív egészségi állapot és a gazdasági aktivitás, valamint a jövedelmi viszonyok között. A heti munkaidő mennyisége nem befolyásolja statisztikailag mérhető szinten az önminősített egészségi állapotot. Adekvát statisztikai összefüggést találtunk azonban az egészségmegőrzés lehetősége és a gazdaságiaktivitás-változók között, viszont nem találtunk bizonyítható összefüggést a jövedelmi viszonyok jellemzőivel.

Az alábbi táblázat adatai egyértelmú képet festenek a munkaerőpiaci helyzet és az önminősített egészség összefüggéseiről. Azok, akik dolgoztak a megkérdezéskor, jóval nagyobb százalékban vélekednek úgy, hogy "nagyon jó”, illetve „jó” az egészségi állapotuk (70\%). Mindkét kategóriában jelentős eltérést tapasztalunk a nem dolgozók véleménynyilvánításához viszonyítva $(36,7)$. A vizsgálat idején nem dolgozó válaszadók közül minden ötödik személy minősítette saját egészségi állapotát „rossz”-nak vagy „nagyon rossz”-nak. Ez a mutató a dolgozók csoportjában minden 43. személyre igaz. [11. táblázat]

Vélhetően ezzel is összefügg, hogy egészségi állapotuk befolyásolásában jobban hisznek a dolgozók csoportjába tartozók, mint a nem dolgozók. Utóbbiak esetében minden ötödik válaszadó véli azt, hogy keveset, illetve semmit sem tehet egészsége érdekében. A másik csoportban ez nagyjából minden 10. személyre igaz. [12. táblázat]

11. táblázat: Hogyan jellemezné általában egészségi állapotát? (\%)

\begin{tabular}{|c|c|c|c|c|c|c|c|}
\hline $\begin{array}{c}\text { Dolgozik-e jelenleg? } \\
\text { N=379 }\end{array}$ & $\begin{array}{c}\text { Nagyon } \\
\text { jó }\end{array}$ & Jó & Elfogadható & Rossz & $\begin{array}{c}\text { Nagyon } \\
\text { rossz }\end{array}$ & Összesen \\
\hline Igen & 21,3 & 45,7 & 30,8 & 2,3 & 0,0 & 100,0 \\
\hline Nem & 12,0 & 24,7 & 44,9 & 15,2 & 3,2 & 100,0 \\
\hline
\end{tabular}

$p^{<0,001}$

Forrás: saját szerkesztés 
12. táblázat: Véleménye szerint Ön mennyit tehet az egészségéért? (\%)

\begin{tabular}{|c|c|c|c|c|}
\hline $\begin{array}{c}\text { Dolgozik-e jelenleg? } \\
\text { N=376 }\end{array}$ & Nagyon sokat & Sokat & Keveset & \multicolumn{2}{c|}{ Semmit } \\
\hline Igen N=222 & 37,4 & 53,2 & 8,1 & 1,4 \\
\hline Nem N=154 & 26,6 & 47,4 & 19,5 & 6,5 \\
\hline
\end{tabular}

$p^{<0,001}$

Forrás: saját szerkesztés

A nyíregyháziak jövedelmi helyzete egyre kedvezőbben alakul az elmúlt évekhez viszonyítva. A javulás mértéke 2015 után gyorsult fel igazán. Ettől kezdve a foglalkoztatás színvonalában, a nettó- és mediánjövedelemben is jelentős emelkedés tapasztalható. ${ }^{19}$

Eredményeink szerint a nagyon jó egészségi állapotról vallók százalékos megoszlása a 201 ezer forintos nettó jövedelemmel bírók csoportjától kezdve emelkedik jelentősebb méretékben. Azok, akik 201250 ezer forint közötti jövedelemből élnek, 18\%ban értékelik saját egészségi állapotukat „nagyon jó"-nak. Ez a megoszlás a legmagasabb jövedelmi csoportban 23,5\%. A "rossz” és „nagyon rossz" válaszlehetőséget a két legalacsonyabb jövedelmi kategóriába tartozók választották a legtöbben. [13. táblázat]

13. táblázat: Hogyan jellemezné általában egészségi állapotát? (\%)

\begin{tabular}{|c|c|c|c|c|c|c|}
\hline Havi nettó jövedelem (\%) & $\begin{array}{c}\text { Nagyon } \\
\text { jó }\end{array}$ & Jó & Elfogadható & Rossz & $\begin{array}{c}\text { Nagyon } \\
\text { rossz }\end{array}$ & Összesen \\
\hline legfeljebb 50 ezer Ft & 0,0 & 25,0 & 25,0 & 25,0 & 25,0 & 100,0 \\
\hline 51-100 ezer Ft & 11,8 & 23,5 & 44,1 & 14,7 & 5,9 & 100,0 \\
\hline $101-150$ ezer Ft & 7,0 & 36,8 & 47,4 & 8,8 & 0,0 & 100,0 \\
\hline $151-200$ ezer Ft & 12,0 & 28,0 & 46,0 & 14,0 & 0,0 & 100,0 \\
\hline $201-250$ ezer Ft & 18,0 & 46,0 & 34,0 & 2,0 & 0,0 & 100,0 \\
\hline $251-300$ ezer Ft & 15,4 & 57,7 & 19,2 & 7,7 & 0,0 & 100,0 \\
\hline 300 ezer Ft felett & 23,5 & 38,3 & 34,6 & 2,5 & 1,2 & 100,0 \\
\hline
\end{tabular}

$p^{<0,002}$

Forrás: saját szerkesztés

\section{Összegzés, az eredmények összefoglalása}

Elemző munkánkban a szubjektív egészségi állapot szociológiai vizsgálatát vállaltuk Nyíregyháza lakói körében, egy 2018-ban lebonyolított, empirikus vizsgálatunk alapján. Írásunkban elsősorban a szociodemográfiai, szociokulturális jellemzők, valamit a szocioökonómiai státusz és a szubjektív egészségi állapot összefüggéseit mutattuk be. Arra voltunk kíváncsiak, hogy a megkérdezettek hogyan értékelik saját egészségi állapotukat, és hogyan vélekednek arról, hogy az egyén maga mennyiben befolyásolhatja egészsége megőrzését. A válaszadók véleménynyilvánítását mindkét kérdés vonatkozásában öt- és négyfokú Likert-skála segítségével mértük. Eredményeink szignifikáns összefüggést mutattak a „Hogyan jellemezné általában egészségi állapotát?” és a családi állapot, az életkor, az iskolai végzettség, a gazdasági aktivitás és a jövedelmi helyzet vonatkozásában. A családi állapot esetében azt tapasztaltuk, hogy a korábbi vizsgálatoknak ellentmondó öszszefüggést mutatnak az adataink, míg a többi 
vizsgált változót illetően a vártnak megfelelő eredmények születtek. Eszerint a fiatalabb életkor, a magasabb iskolai végzettség, a gazdasági aktivitás és a kedvezőbb jövedelmi helyzet pozitívan befolyásolja a szubjektív egészségi állapotot. A családi állapot tekintetében azt tapasztaltuk, hogy az egyedülállók érzik a legjobbnak az egészségi állapotukat. Mindez csak részben magyarázza a családi állapot szubjektív egészségi állapotra gyakorolt hatását, ugyanis az egyedülállók legnagyobb része a 18-25 éves korosztályhoz tartozott. A lefutatott korrelációs számítás szintén az életkori hatás meghatározó voltát erősítette (korrelációs együttható szubjektív egészségi állapot/családi állapot: $r=0,225$; szubjektív egészségi állapot/életkor: $r=0,461$ ).

A „Véleménye szerint Ön mennyit tehet az egészségéért?" kérdésre adott válaszok mintázatában a bevont magyarázó változók közül az életkor, az iskolai végzettség és a gazdasági aktivitás bizonyító erejét tártuk fel. Eredményeink szerint a fiatalabbak, a magasabb iskolai végzettséggel bírók és a fizetett munkát végzők gondolják úgy, hogy hatással lehetnek saját egészségi állapotukra.
Fontos megemlíteni eredményeink azon korlátját, mely a kérdőív egyes kérdéseinek és válaszlehetőségeinek hiányából adódik. A további vizsgálatoknál a családi állapot egyszerű osztályozása mellett érdemes rákérdezni a párkapcsolat érzelmi minőségére, illetve az „Ön dolgozik-e?” kérdésen túl a gazdasági aktivitás teljes körű feltérképezésére. A „nem dolgozók" csoportján belül érdemes tovább vizsgálni, hogy az, aki nem dolgozik, az azért nem dolgozik, mert éppen elveszítette a munkáját, vagy az inaktivitás egyéb kategóriájához sorolható; például nyugdíjas vagy gyermeknevelési szabadságon van. Meglátásunk szerint ezen jellemzők megismerése tovább pontosíthatja az ok-okozati összefüggések feltárását, mely segítheti a helyi egészségfejlesztési koncepció finomhangolását.

A munkával való elégedettség és a szubjektív egészségi állapot összefüggéseinek vizsgálatát szintén fontosnak tartjuk. Jövőbeni célunk a szubjektív egészségi állapot minél pontosabb felmérésén túl a szubjektív jóllét vizsgálata, a Debreceni Egyetem Egészségügyi Kar Egészségszociológiai Tudományos Koordinációs Központ keretei között.

\section{HIVATKOZÁSOK}

${ }^{1}$ Pikó B. Egészségszociológia. Új Mandátum Könyvkiadó, Budapest, 2002.

${ }^{2}$ Libicki É. Társadalmi egyenlőtlenségek egészségszociológiai vizsgálata. Kézirat.

${ }^{3}$ Landa JMA, López-Zafra E, Berrios Martos MP, Aguilar-Luzón MC. The relationship between emotional intelligence, occupational stress and health in nurses: A questionnaire survey. Int J Nurs Stud. 2008:45 (6), 888-901.

doi: 10.1016/j.ijnurstu.2007.03.005

${ }^{4}$ Pikó B, Piczil M. A saját egészség megítélése és a pszichoszociális munkakörnyezet. LAM. 2007:17,65-69. http://www.elitmed.hu/upload/pdf/a sajat egeszseg megitelese es a pszichoszocialis munkakornyezet vizsgalat_a_szabadkai_egeszsegugyi_szakdolgozok_koreben-429.pdf (Elérve: 2019. 10. 27.)

5 Jóna Gy, Erdei R. A szubjektív egészségi állapot meghatározó tényezői Nyíregyházán. Fábián G, Patyán L, Huszti É. (szerk.) Életminőség Nyíregyházán. Nyíregyháza, Magyarország: Debreceni Egyetem Egészségügyi Főiskolai Kar, 2012: 99-115. http://ams.foh.unideb.hu/sites/ams.foh.unideb.hu/files/07 jona erdei.pdf (Elérve: 2019. 10. 27.)

${ }^{6}$ Erdei R, R. Fedor A, Madácsi E. A nyíregyházi lakosok szubjektív egészségi állapota és annak változásai. Acta MedSoc 2014 : 12-13 pp. 189-206. http://ams.foh.unideb.hu/sites/ams.foh.unideb.hu/files/10 02 javorne erdei renata 04.pdf (Elérve: 2019. 10. 17.)

7 Erdei R, Barth A, R. Fedor A, Takács P. Measuring the factors affecting health literacy in East Hungary: Health literacy in the adult population of Nyíregyháza city. Kontakt 2108;20:375-380. doi: 10.1016/j.kontakt.2018.08.007

${ }^{8}$ Deaton A. Income, Health, and Well-being around the World: Evidence from the Gallup World Poll. J Econ Perspec. 2008:22. No. 2. pp. 53-72. doi: 10.1257/jep.22.2.53

${ }^{9}$ Hayo B. Happiness in Transition: An Empirical Study on Eastern Europe. Economic Systems, 2007:31. No. 2. pp. 204-221. doi: 10.1016/j.ecosys.2006.08.003

${ }^{10}$ Molnár Gy, Kapitány Zs. Miért elégedetlenek annyira a magyarok az életükkel? Múhelytanulmányok. MTA Közgazdaság-és Regionális Tudományi Kutatóközpont Közgazdaság-tudományi Intézet. 2013. http://econ.core.hu/file/download/mtdp/MTDP1347.pdf. (Elérve: 2019. 10. 01.) 
${ }^{11}$ Kopp M, Mészáros E. Az életminőség és a jóllét társadalmi-gazdasági különbségei Magyarországon. Megjelent: Európai lakossági egészségfelmérés. Tanulmányok II. Az egészség társadalmi, gazdasági összefüggései. Központi Statisztikai Hivatal, Budapest, 2012:9-32.

${ }^{12}$ Caporale GM, Georgellis Y, Tsitsianis N, Yin. Income and Happiness Across Europe: Do reference Values Matter? J Econ Psychol. 2009:30. pp. 42-51. doi: 10.1016/j.joep.2008.06.004

${ }^{13}$ Hüse L. A szubjektív egészségi állapot tényezői és azok változásai Nyíregyházán és vonzáskörzetében. Acta MedSoc 2015:18-19 pp. 96-120. http://ams.foh.unideb.hu/sites/ams.foh.unideb.hu/files/acta ms vol6 no18-19_06 huse.pdf (Elérve: 2019. 10. 27.)

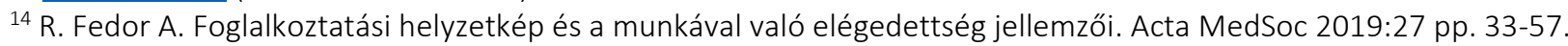
doi: 10.19055/ams.2018.9/27/4

${ }^{15}$ R. Fedor A. Labor Market Participation of Women Living in the North Great Plain Region. Hum. Innov. Szle. 2018:1-2 pp. 32-53. http://humanexchange.hu/site/uploads/HISZ 2017-2018.pdf (Elérve: 2019. 10. 26.)

${ }^{16} \mathrm{R}$. Fedor A. The power of theoretical models to explain the presence of women in the labor market based upon a survey of eastern hungarian women. Taylor: Gazdálkodás- és Szervezéstudományi Folyóirat: A virtuális intézet KözépEurópa kutatására közleményei 2018:1 pp. 91-101. http://vikek.eu/wp-content/uploads/2018/04/TaylorNo31.pdf (Elérve: 2019. 10. 27.)

${ }^{17}$ R. Fedor A, Toldi A. Labour market opportunities of women with young children after childbirth. Kontakt 2017: 3 pp. 220-226. doi: $10.1016 /$ j.kontakt.2017.07.003

${ }^{18}$ Clark AE. Work, Jobs and Well-being Across the Millennium. Diener E, Helliwell J, Kahneman D. (szerk.): International Differences in Well-being. Oxford University Press, Oxford. 2010. http://ftp.iza.org/dp3940.pdf (Elérve: 2019. 10. 27.)

${ }^{19}$ Fábián G, Takács P, Szigeti F. Jövedelmi helyzet, jövedelmi egyenlőtlenségek. Acta MedSoc 2018:9, pp. 58-69. http://ams.foh.unideb.hu/sites/ams.foh.unideb.hu/files/acta ms vol6 no18-19 - 04 fabian-takacs-szigeti.pdf (Elérve: 2019. 10. 27.) 